\title{
MANAJEMEN STRATEGI PELAKSANAAN KURIKULUM DALAM MEWUJUDKAN MADRASAH UNGGUL (Studi atas MA Muhammadiyah Kota Metro)
}

\author{
Sujino \\ Fakultas Agama Islam Universitas Muhammadiyah Metro \\ sujinosaja77@gmail.com
}

\begin{abstract}
The public demand for quality or quality education is increasing. This phenomenon is at least influenced by two main factors namely; factors of globalization challenges and parents' awareness of the need for quality or quality education for their children. Another phenomenon that is not less interesting, today many schools are qualified and give more religious content became the first choice for parents, this condition is a challenge as well as opportunities for Senior High School (MA) Muhammadiyah Metro City to rise from the shackles of dualism that is artificial and dualism management at once showcasing the various advantages that can be an attraction at the same time can invite public interest to make this institution as an option for the continuation of their children's education. This study aims to analyze management and strategy Implementation of the curriculum in realizing Senior High School (MA) Muhammadiyah Metro City Becomes a Superior School. This type of research is descriptive qualitative in which the data collection in this study was conducted by the method of observation, interview, and documentation study. Data that have been collected is then analyzed descriptively qualitative to then drawn conclusions. The results of this study will show that the management and implementation strategy of the curriculum in realizing Senior High School Muhammadiyah Metro City becomes a superior school. The results of this study recommend to management tiem in the implementation of the curriculum in realizing Senior High School Muhammadiyah Metro City Becomes a Superior School.
\end{abstract}

Keywords: Managemen, Strategy, Curriculum

\begin{abstract}
Abstrak
Tuntutan masyarakat terhadap pendidikan yang bermutu atau berkualitas semakin meningkat. Fenomena ini paling tidak dipengaruhi oleh dua faktor utama yaitu; faktor tantangan globalisasi dan faktor kesadaran orangtua akan perlunya pendidikan yang bermutu atau berkualitas bagi anak-anaknya. Fenomena lain yang tidak kalah menariknya, dewasa ini banyak sekolah yang bermutu dan memberi muatan agama lebih banyak menjadi pilihan pertama bagi orangtua, kondisi yang demikian ini merupakan tantangan sekaligus peluang bagi Madrasah Aliyah Muhammadiyah Kota Metro untuk bangkit dari belenggu dualisme yang artifisial dan dualisme pengelolaan sekaligus menampakkan berbagai keunggulan yang dapat menjadi daya tarik sekaligus dapat mengundang animo masyarakat untuk
\end{abstract}


menjadikan lembaga ini sebagai pilihan bagi kelanjutan pendidikan anakanak mereka. Penelitian ini bertujuan untuk menganalisis manajemen dan strategi Pelaksanaan kurikulum dalam mewujudkan Madrasah Aliyah Muhammadiyah Kota Metro menjadi sekolah unggul. Jenis penelitian ini bersifat deskriptif kualitatif di mana pengumpulan data dalam penelitian ini dilaksanakan dengan metode observasi, wawancara, dan studi dokumentasi. Data yang telah dihimpun tersebut kemudian di analisis secara deskriptif kualitatif untuk kemudian ditarik kesimpulan. Hasil penelitian ini nantinya menunjukkan bahwa manajemen dan strategi pelaksanaan kurikulum dalam mewujudkan Madrasah Aliyah Muhammadiyah Kota Metro menjadi sekolah unggul. Hasil penelitian ini merekomendasikan kepada tim manajemen dalam pelaksanaan kurikulum dalam mewujudkan Madrasah Aliyah Muhammadiyah Kota Metro Menjadi Sekolah Unggul.

Kata Kunci: Manajemen, Strategi, Kurikulum

\section{A. PENDAHULUAN}

Tuntutan masyarakat terhadap pendidikan yang unggul atau berkualitas semakin meningkat. Fenomena ini paling tidak dipengaruhi oleh dua faktor utama yaitu; faktor tantangan globalisasi dan faktor kesadaran orangtua yang sadar akan perlunya pendidikan yang unggul atau berkualitas bagi anak-anaknya.

Faktor tantangan globalisasi, melahirkan tuntutan perlunya sumber daya manusia yang berkualitas, karena persaingan global dalam era pasar bebas akan melahirkan kompetisi yang keras dan untuk mengambil peran di era ini setiap individu dituntut memiliki keuletan, kedisiplinan, etos kerja yang tinggi, pandai menangkap peluang, serta memiliki semangat untuk terus belajar. Kualitas sumber daya manusia tidak hanya diukur dengan pendidikan dan keterampilan semata, namun juga berkaitan dengan mentalitas yang dilandasi sistem moral yang etis dalam perilakunya. ${ }^{1}$ Dengan adanya globalisasi akan timbul pemikiran,

1 Nurcholis Madjid, Islam Doktrin Dan Peradaban: Sebuah Telaah Kritis Tentang Masalah Keimanan, Kemanusiaan Dan Kemoderenan:, Jakarta: Yayasan wakaf paramadina, 1992, h. 30 usulan dan usaha serta kemampuan di seluruh dunia yang dengan sangat cepat dan mudah untuk diakses sehingga dapat memberikan kesempatan baru bagi peneliti atau ilmuwan untuk menganalisis, mengadopsi berbagai bentuk kegiatan pendidikan $^{2}$

Faktor kesadaran orangtua terhadap pendidikan yang berkualitas lahir, semula didasari pada kesadaran ekonomis bahwa pendidikan adalah sebuah investasi bagi diri dan anak-anak mereka, yang kemudian berkembang bahwa pendidikan merupakan "industri jasa" sehingga mereka berhak untuk meminta layanan yang berkualitas. Ekses dari kesadaran inilahh maka sekolah unggulan semakin dicari. Hal ini memunculkan adanya sekolah-sekolah unggulan yang menyebar diberbagai kota kecil maupun kota besar. ${ }^{3}$ Dengan demikian faktor globalisasi dan

${ }^{2}$ M.Ihsan Dacholfany, Reformasi Pendidikan Islam Dalam Menghadapi Era Globalisasi: Sebuah Tantangan Dan Harapan, Jurnal Akademika, Vol. 20, No. 01 januari - juni 2015, h. 174

${ }^{3}$ Ali Imron, Supervisi Pembelajaran Tingkat Satuan Pendidikan, Jakarta: Bumi Aksara . 2011, h. 16 
kesadaran orangtua menjadi hal yang sangat penting untuk menjadikan peserta didik untuk dapat lebih maju dan berkembang walaupun dengan tantangan dan masalah yang harus diselesaikan secara teliti, semangat dan tanggung jawab bersama untuk menjadikan manajemen dan strategi Pelaksanaan kurikulum dalam mewujudkan Madrasah Aliyah Muhammadiyah Kota Metro menjadi Sekolah Unggul dapat tercapai dengan baik.

Fenomena lain yang tidak kalah menariknya dewasa ini, bahwa sekolahsekolah yang unggul dan memberi muatan agama lebih menjadi pilihan bagi orang tua, kondisi yang demikian ini merupakan tantangan sekaligus peluang bagi Madrasah Aliyah Muhammadiyah (selanjutnya disingkat MAM) Kota Metro untuk bangkit dari belenggu dualisme yang artifisial dan dualisme pengelolaan sekaligus menampakkan berbagai keunggulan yang dapat menjadi daya tarik sekaligus dapat mengundang animo masyarakat untuk menjadikan lembaga ini sebagai pilihan bagi kelanjutan pendidikan anak-anaknya.

Keunggulan MAM Kota Metro secara umum dapat tergambar dari kemampuannya untuk melaksanakan prinsip-prinsip sekolah efektif, berpredikat (sebagai Madrasah Keagamaan, Madrasah Model dan Madrasah Terpadu), serta prestasi-prestasi yang diperolehnya.

Guna memposisikan statusnya menjadi lembaga pendidikan yang unggul, MAM Kota Metro berusaha untuk mengupayakan dan memberdayakan seluruh potensi pendidikan yang dimiliki secara efektif, selektif, efesien, terpadu dan berkesinambungan, salah satunya adalah "kurikulum pendidikan" karena kurikulum merupakan sarana untuk mewujudkan visi, misi, tujuan dan sasaran yang diharapkan.

Metode pelaksanaan kurikulum tidak saja yang berhubungan dengan penyajian materi kurikulum dalam pembelajaran, tetapi juga melibatkan hal-hal yang terkait dengan kurikulum, misalnya pelaksanaan sistem evaluasi, pelaksanaan bimbingan, dan pengadministrasian, yang kesemuanya dipandang sebagai suatu unsur dan sistem persekolahan yang dapat didesain dan direncanakan untuk menciptakan terjadinya proses pembelajaran yang relevan.

Berdasarkan uraian di atas nyatalah bahwa pengembangan madrasah menjadi sekolah unggul salah satu di antaranya dapat dilaksanakan melalui penerapan strategi pelaksanaan kurikulum secara maksimal serta mendapat dukungan penuh dari seluruh tenaga kependidikan yang berperan aktif di madrasah tersebut. Untuk mengetahui seberapa besar penerapan manajemen strategi pengembangan MAM Kota Metro menjadi sekolah unggul dan daya dukung yang diberikan oleh tenaga kependidikan dalam mewujudkan berbagai keunggulan di Madrasah, maka penelitian ini dapat dilaksanakan dengan baik.

Melihat betapa pentingnya manejemen peningkatan mutu lulusan lembaga pendidikan, agar dapat dalam mengimplementasikannya tujuan ideal sebuah lembaga lembaga pendidikan dapat tercapai dan memuaskan masyarakat, stakeholder dan orang tua. Dengan ini penulis menyimpulkan beberapa permasalahannya:

Dari latar belakang pemikiran sebagaimana yang digambarkan pada pembahasan di atas maka fokus penelitian ini ditekankan pada aspek penerapan 
manajemen strategi pelaksanaan kurikulum dalam mewujudkan Madrasah Aliyah Muhammadiyah Metro menjadi sekolah unggul. Dari penekanan ini maka rumusan masalah dari penelitian ini.

1. Bagaimana Struktur Kurikulum Madrasah Aliyah Muhammadiyah Metro menjadi sekolah unggul ?

2. Bagaimana Muatan Kurikulum Madrasah Aliyah Muhammadiyah Metro menjadi sekolah unggul ?

3. Bagaimana Strategi Pendidikan dan Pembelajaran Madrasah Aliyah Muhammadiyah Metro menjadi sekolah unggul ?

4. Apa saja Keunggulan Madrasah Aliyah Muhammadiyah Metro ?

\section{B. METODE PENELITIAN}

Jenis penelitian ini adalah penelitian deskriptif kualitatif penelitian kualitatif adalah metode penelitian yang berlandaskan pada filsafat postpositivisme, digunakan untuk meneliti pada kondisi objek yang alamiah, (sebagai lawannya adalah eksperimen) dimana peneliti adalah sebagai instrumen kunci, pengambilan sampel sumber data dilakukan secara purposive dan snowball, teknik pengumpulan dengan trianggulasi (gabungan) analisis data bersifat induktif/kualitatif dan hasil penelitian kualitatif lebih menekankan makna dari pada generalisasi ${ }^{4}$, maka pengumpulan data dalam penelitian ini menggunakan metode observasi berperan serta (participation observation), wawancara mendalam dan dokumentasi.

${ }^{4}$ Sugiyono, Metode Penelitian Pendidikan (Pendekatan Kuantitatif, Kualitatif, dan $R \& D)$,(Bandung: Alfabeta, 2010),h.43.

\section{KAJIAN TEORI}

\section{Manajemen Strategis}

Manajemen strategis adalah serangkaian keputusan dan tindakan manjerial yang menentukan kinerja perusahaan dalam jangka panjang. Menurut Fred R. David, manajemen strategis adalah seni dan pengetahuan untuk merumuskan, mengimplementasikan dan mengevaluasi keputusan lintas fungsional yang membuat organisasi mampu mencapai objektifnya ${ }^{5}$.

Menurut Tunggal Amin Widjaja ${ }^{6}$ manajemen srategis terdiri dari sembilan tugas kritikal berikut ini :

1. Memformulasi misi (mission) perusahaan termasuk pernyataan yang luas mengenai maksud, falsafah, dan sasaran.

2. Mengembangkan suatu profil perusahaan yang merefleksi pada kondisi internal dan kemampuannya.

3. Menilai lingkungna eksternal perusahaaan.

4. Menganalisii opsi perusahaan dengan menandingi sumber daya perusahaan dngan lingkungan eksternalnya.

5. Mengidentifikasi opsi yang paling diinginkan dengan menilai setiap opsi dipandang dari sudut misi perusahaan.

6. Memimlih sekumpulan tujuan jangka panjang dan strategi total yang akan mencapi opsi yang paling diinginkan.

7. Mengembangkan tujuan tahunan dan strategi jangka pendek yang sesai dengan kumpulan tujuan jangka panjang yang dipilih dari strategi sacara keseluruhan.

5 Fred David, Manajemen Strategis, Jakarta 2006:, Salemba, Ce.-4, h. 4

6 Tunggal Amin Widjaja, Audit Manajemen, Jakarta, h.6 
8. Mengimplementasikan pilihan strategi dengan alat alokasi sumberdaya yang dianggarkan yaitu memadai tugastugas, manusia, struktur, teksnologi, dan menekankan sistem ganjaran.

9. Menilai keberhasilan proses stratejk sebagai masukan untuk pengambilan keputusan dimasa yang akan datang.

Menurut Wheelen dan Hunger ${ }^{7}$, proses manajemen strategis meliputi 4 elemen dasar, yaitu: (1). Pengamatan lingkungan, (2). Perumusan strategi, (3). Implementasi strategi dan (4). Evaluasi dan pegendalian.

\section{Kurikulum Unggul}

Agar dapat bersaing secara global, pengelolaan kurikulum pada dasarnya mengandung 4 sub bidang manajemen, sebagaimana dikonsepsikan oleh White (2008: 37), yaitu; (1) manajemen sumber daya manusia (berhubungan dengan pengelolaan SDM selaku pembuat dan pelaksana kurikulum serta pensukses aplikasinya bagi anak didik), manejemen pembelajaran (berhubungan dengan pengelolaan dan penggunaan metode, materi dan proses pembelajaran yang tepat dan sesuai dengan kebutuhan anak didik dan kebutuhan masyarakat), (3) manajemen fasilitas (berhubungan dengan pengelolaan seluruh fasilitas pendidikan yang ada di sekolah) dan (4) manajemen penilaian (berhubungan dengan upaya evaluasi terhadap performa hasil dari pelaksanaan kurikulum di sekolah). Keempat sub bidang manajemen tersebut bersifat integratif, artinya saling mendukung, mempengaruhi dan menentukan keberhasilan pelaksanaan

${ }^{7}$ Wheelen dan Hunger, Manajemen Stratejik, Terj. Julianto Agung, Yaogyakarta, Penerbit Andi, 2008, h. 8-9 kurikulum di madrasah. Misalnya, materi kurikulum sudah baik, namun ketika tanpa didukung oleh pengelolaan sumber daya manusia (SDM) yang juga baik niscaya orientasi yang hendak dicapai oleh madrasah tidak akan dapat diwujudkan. Begitu juga dengan peran penilaian dalam mengukur sekaligus mengevaluasi sampai sejauh mana pencapaian yang telah diperoleh harus betul-betul dapat dimanfaatkan sebagai balikan (feed back) yang efektif ${ }^{8}$.

\section{Pengembangan Madrasah Menjadi Sekolah Unggul}

Mengembangkan madrasah menjadi sekolah unggul di Indonesia, selain merupakan tuntutan kelembagaan dalam memasuki percaturan pendidikan nasional juga merupakan tuntutan masyarakat pengguna pendidikan.

Tafsir menyatakan bahwa mengembangkan madrasah secara kelembagaan berarti mengembangkan seluruh komponen pendidikan atau lazim disebut gugusan madrasah yang meliputi kurikulum, ketenagaan, siswa, sarana prasarana, dana dan hubungan masyarakat. Lebih lanjut Tafsir juga menekankan perlunya sikap positif pemerintah dan masyarakat (khususnya umat Islam) terhadap lembaga pendidikan Islam atau madrasah serta teori-teori pendidikan yang modern dan islami dalam mendukung kemajuan madrasah dimasa yang akan datang ${ }^{9}$, maka menurut penulis perlu adanya visi dan misi serta tujuan dalam mengembangkan madrasah, antara lain

8 Muhammad Thoyib , Respons Madrasah Terhadap Globalisasi, journal.uinsgd., Vol. XXVIII No. 1 2013/1434, h.

9 A. Tafsir , Strategi Meningkatkan Mutu Pendidikan Agama Islam, Bandung: Maestro, 2008, h. 3. 
adalah kreatif, populis, unggul islami dan bermutu. Dengan demikian Perkembangan yang paling aktual saat ini adalah makin tingginya aspirasi masyarakat terhadap pendidikan, dan gencarnya tuntutan kebijakan pendidikan yang meliputi peningkatan aspek-aspek pemerataan kesempatan, mutu, efisiensi dan relevansi 10

Untuk mencapai derajat keunggulan, maka pengembangan madrasah tidak terlepas dari pemikiran mengenai kurikulum ideal dan kurikulum aktual (ideal curriculum and actual curriculum), maksudnya, pengembangan madrasah sama artinya dengan pembenahan kurikulum baik dalam arti ideal maupun aktual. Pembenahan kurikulum ideal adalah pembenahan subtansi dari kurikulum yang perlu di transformasikan dalam proses pembelajaran. Pembenahan kurikulum ideal ini perlu diikuti kemampuan untuk merealisasikan subtansi tersebut, sebab tidak ada artinya kurikulum ideal yang bagus tanpa ada upaya untuk mengimplementasikannya melalui kurikulum aktual, antara ideal kurikulum dan aktual kurikulum selalu ada "gap", artinya sering kali dalam proses pembelajaran tidak dapat terlaksana penuh apa yang diharapkan oleh karena itu perlu disiasati (perlu ada strategi) dalam pelaksanaannya sehingga tingkat "gap" dapat dipersempit.

Husni Rahim menjelaskan ada tiga bentuk kegiatan yang harus dilakukan dalam mensiatati kurikulum madrasah yaitu: (1) Program Mafikibb (Matematika, Fisika, Kimia, Biologi dan Bahasa Asing) dengan nuansa Islam. (2) Program pelajaran agama dengan nuansa Iptek. (3) Program penciptaan suasana keagamaan di Madrasah ${ }^{11}$.

\section{PEMBAHASAN}

Berdirinya Madrasah Aliyah Muhammadiyah Metro pada mulanya tidak lepas dari adanya Pendidikan Guru Agama (PGA) selama 6 (enam) tahun yang telah ada jauh sebelum tahun 1982 . Madrasah Aliyah Muhammadiyah sejak awal berdirinya terus berkomitmen menyelenggarakan Pendidikan dan Pembelajaran berbasis nilai-nilai islam dengan tetap mengacu pada system pendidikan nasional yang ada pada saat itu. Seiring berjalannya waktu dan berubahnya zaman, Madrasah Aliyah harus pula mengikuti tuntutan dan perkembangan zaman, maka status Madrasah Aliyah harus pula di setarakan dengan sekolah di bawah naungan Departemen Pendidikan dan Kebudayaan. Maka dengan dikeluarkannya UU RI No. 2 Tahun 1999 tentang System Pendidikan Nasional dan PP No. 28 Tahun 1998 tentang Pendidikan Nasional, serta berdasarkan Keputusan Departemen Pendidikan dan Kebudayaan RI No.0498/V/1992 tentang sekolah umum dalam pasal 1 ayat 6 disebutkan bahwa Madrsah Aliyah adalah sama dengan SMU yang berciri khas agama Islam yang diselenggarakan oleh Departemen Agama $^{12}$.

11 Husni Rahim, Arah Baru Pendidikan Islam

di Indonesia, Jakarta: Logos, 2001, h.140.

12 Wawancara dengan Kepala MAM, Ahmad Kholil, kepala MA Muhammadiyah Metro, tanggal 10 Oktober 2017. 


\section{Struktur Kurikulum MA Muhammadiyah Metro}

Setruktur kurikulum MAM Metro meliputi substansi pembelajaran yang ditempuh dalam satu jenjang pendidikan selama tiga tahun mulai kelas $\mathrm{X}$ sampai dengan kelas XII. Setruktur kurikulum disusun berdasarkan standar kompetensi lulusan dan standar kompetensi mata pelajaran.

Pengorganisasian kelas-kelas pada MAM Metro dibagi ke dalam dua kelompok, yaitu kelas $\mathrm{X}$ merupakan program umum yang diikuti oleh seluruh peserta didik, dan kelas XI dan XII merupakan program penjurusan yang terdiri atas dua program : (1) Program Ilmu Pengetahuan Alam dan (2) Ilmu Pengetahuan Sosial.

\section{Kurikulum MAM Metro Kelas X}

Kurikulum MAM Metro kelas X terdiri atas 20 mata pelajaran, muatan lokal, dan pengembangan diri. Muatan lokal merupakan kegiatan intrakurikuler untuk mengembangkan kompetensi yang disesuaikan dengan ciri khas dan potensi daerah, termasuk keunggulan daerah yaitu Tapis dan Tari Lampung, yang materinya tidak dapat dikelompokan ke dalam mata pelajaran yang ada.

Pengembangan diri bukan merupakan mata pelajaran yang harus diasuh oleh guru. Pengembangan diri bertujuan memberikan kesempatan kepada peserta didik untuk mengembangkan dan mengekspresikan diri sesuai dengan kebutuhan, bakat dan minat setiap peserta didik sesuai dengan kondisi sekolah. Kegiatan pengembangan diri difasilitasi dan atau dibimbing oleh konselor, guru, atau tenaga kependidikan yang dapat dilakukan dalam bentuk kegiatan

ekstrakurikuler. Kegiatan pengembangan diri dilakukan melalui kegiatan pelayanan konseling yang berkenaan dengan masalah diri pribadi dan kehidupan sosial, belajar dan pengembangan karir peserta didik.

1. Jam pelajaran untuk setiap mata pelajaran dialokasikan sebagaimana tertera dalam setruktur kurikulum MAM Metro menerapkan 48 jam pembelajaran perminggu secara keseluruhan

2. Alokasi waktu dalam satu jam pembelajaran adalah 45 menit

3. Minggu efektif dalam satu tahun pelajaran (dua semester) adalah 36 minggu

Adapun struktur kurikulum MAM Metro kelas X berdasarkan KTSP dapat dilihat pada tabel di bawah ini :

Tabel. 1 Struktur Kurikulum Madrasah Aliyah MuhammadiyahMetro kelas X

\begin{tabular}{|c|c|c|}
\hline KOMPONEN & \multicolumn{2}{|c|}{ Alokasi Waktu } \\
\hline Mata Pelajaran & Sem 1 & Sem 2 \\
\hline 1. Al-Qur'an Hadits & 4 & 4 \\
\hline 2. Fikih & 4 & 4 \\
\hline 3. Akidah Akhlak & 2 & 2 \\
\hline 4. SKI & 2 & 2 \\
\hline 5. Bahasa Arab & 2 & 2 \\
\hline 6. Bahasa Inggris & 2 & 2 \\
\hline 7. Bahasa Indonesia & 2 & 2 \\
\hline 8. Fisika & 2 & 2 \\
\hline 9. Biologi & 2 & 2 \\
\hline 10. Kimia & 2 & 2 \\
\hline 11. Sejarah & 2 & 2 \\
\hline 12. Geografi & 2 & 2 \\
\hline 13. Ekonomi & 2 & 2 \\
\hline 14. Sosiologi & 2 & 2 \\
\hline 15. Matematika & 2 & 2 \\
\hline 16. Pen. Kwar & 2 & 2 \\
\hline 17. PENJASKES & 2 & 2 \\
\hline Kelompok Mapel Khusus & & \\
\hline 18. Ket. Agama & 2 & 2 \\
\hline 19. KMD & 2 & 2 \\
\hline 20. Seni budaya & 2 & 2 \\
\hline 21. TIK & 2 & 2 \\
\hline $\begin{array}{l}\text { B. Muatan Lokal (Desaign } \\
\text { Tapis) }\end{array}$ & 2 & 2 \\
\hline JUMLAH & 48 & 48 \\
\hline
\end{tabular}


Tabel 2. Kurikulum MAM Metro kelas XI dan XII

\begin{tabular}{|c|c|c|c|c|}
\hline \multirow{3}{*}{$\begin{array}{c}\text { Komponen } \\
\text { A. Mata Pelajaran }\end{array}$} & \multicolumn{4}{|c|}{ Alokasi Waktu } \\
\hline & \multicolumn{2}{|c|}{ Kelas XI } & \multicolumn{2}{|c|}{ Kelas XII } \\
\hline & Smt 1 & Smt 2 & Smt 1 & $\begin{array}{c}\text { Smt } \\
2\end{array}$ \\
\hline $\begin{array}{l}\text { 1. Al Qur'an } \\
\text { Hadis }\end{array}$ & 2 & 2 & 2 & 2 \\
\hline 2. Fikih & 2 & 2 & 2 & 2 \\
\hline 3. Akidah Ahlak & 2 & 2 & 2 & 2 \\
\hline $\begin{array}{ll}4 . & \text { Sejarah } \\
\text { Kebudayaan } \\
\text { Islam }\end{array}$ & & & 2 & 2 \\
\hline 5. Bahasa Arab & 3 & 3 & 3 & 3 \\
\hline $\begin{array}{l}\text { 6. } \\
\text { Pendidikan } \\
\text { Kewaganegar } \\
\text { aan }\end{array}$ & 2 & 2 & 2 & 2 \\
\hline $\begin{array}{ll}\text { 7. } & \text { Bahasa } \\
\text { Indonesia }\end{array}$ & 4 & 4 & 4 & 4 \\
\hline $\begin{array}{l}\text { 8. Bahasa } \\
\text { Inggris }\end{array}$ & $4+1$ & $4+1$ & 4 & 4 \\
\hline 9. Matematika & $4+1$ & $4+1$ & $4+1$ & $4+1$ \\
\hline 10. Fisika & $4+1$ & $4+1$ & 4 & 4 \\
\hline 11. Kimia & 4 & 4 & 4 & 4 \\
\hline 12. Biologi & 4 & 4 & 4 & 4 \\
\hline 13. Sejarah & 1 & 1 & 1 & 1 \\
\hline 14. Seni Budaya & 2 & 2 & 2 & 2 \\
\hline $\begin{array}{l}\text { 15. Pendidikan } \\
\text { Jasmani, } \\
\text { Olahraga dan } \\
\text { Kesehatan } \\
\end{array}$ & 2 & 2 & 2 & 2 \\
\hline $\begin{array}{l}\text { 16. Teknologi } \\
\text { Informasi dan } \\
\text { Komunikasi }\end{array}$ & 2 & 2 & 2 & 2 \\
\hline $\begin{array}{l}\text { 17. Ketrampilan } \\
\text { (Kaligrafi) }\end{array}$ & 2 & 2 & 2 & 2 \\
\hline $\begin{array}{l}\text { B. Muatan Lokal ( } \\
\text { Tari Lampung kls } \\
\text { XII dan Tapis } \\
\text { Lampung XI) }\end{array}$ & 2 & 2 & 2 & 2 \\
\hline Jumlah & 49 & 49 & 49 & 49 \\
\hline
\end{tabular}

Kurikulum MAM Metro kelas XI dan XII program IPA, dan Program IPS terdiri dari 13 mata pelajaran, muatan lokal dan pengembangan diri. Muatan lokal merupakan kegiatan kurikuler untuk mengembangkan kompetensi yang disesuaikan dengan ciri khas dan potensi daerah, termasuk keunggulan daerah, yang materinya tidak dapat dikelompokan ke dalam mata pelajaran yang ada, subtansi muatan lokal ditentukan oleh satuan pendidikan.

Pengembangan diri bukan merupakan mata pelajaran yang harus diasuh oleh guru. Pengembangan diri bertujuan memberikan kesempatan kepada peserta didik untuk mengembangkan dan mengekspresikan diri sesuai dengan kebutuhan, bakat, dan minat setiap peserta didik sesuai dengan kondisi sekolah. Kegiatan pengembangan diri difasilitasi dan atau dibimbing oleh konselor, guru, atau tenaga kependidikan yang dapat dilakukan dalam bentuk kegiatan ekstrakurikuler. Kegiatan pengembangan diri dilakukan melalui kegiatan pelayanan konseling yang berkenaan dengan masalah diri pribadi dan kehidupan sosial, belajar, dan pengembangan karir peserta didik.

Alokasi waktu satu jam pembelajaran adalah 45 menit. Minggu efektif dalam satu tahun pelajaran (dua semester) adalah 36 minggu. 


\section{Muatan Kurikulum}

Struktur dan muatan Kurikulum Madrasah Aliyah Muhammadiyah tertuang dalam SI meliputi lima kelompok mata pelajaran sebagai berikut.

a. Kelompok mata pelajaran agama dan akhlak mulia

b. Kelompok mata pelajaran kewarganegaraan dan kepribadian

c. Kelompok mata pelajaran ilmu pengetahuan dan teknologi

d. Kelompok mata pelajaran estetika

e. Kelompok mata pelajaran jasmani, olahraga dan kesehatan

Kelompok mata pelajaran tersebut dilaksanakan melalui muatan dan/atau kegiatan pembelajaran sebagaimana diuraikan dalam PP 19/2005 Pasal 7. Muatan Kurikulum Madrasah Aliyah Muhammadiyah Metro meliputi sejumlah mata pelajaran yang keluasan dan kedalamannya merupakan beban belajar bagi peserta didik pada satuan pendidikan.

Di samping itu materi muatan lokal dan kegiatan pengembangan diri termasuk ke dalam isi kurikulum. Cakupan setiap kelompok mata pelajaran disajikan pada Tabel sebagai berikut.

Tabel 3. Cakupan setiap kelompok mata pelajaran

\begin{tabular}{|c|l|l|}
\hline No & $\begin{array}{c}\text { Kelompok } \\
\text { Mata } \\
\text { Pelajaran }\end{array}$ & \multicolumn{1}{|c|}{ Cakupan } \\
\hline 1. & $\begin{array}{l}\text { Agama } \\
\text { dan } \\
\text { Akhlak } \\
\text { Mulia }\end{array}$ & $\begin{array}{l}\text { Kelompok mata pelajaran agama } \\
\text { dan akhlak mulia dimaksudkan } \\
\text { untuk membentuk peserta didik } \\
\text { menjadi manusia yang beriman } \\
\text { dan bertakwa kepada Tuhan Yang } \\
\text { Maha Esa serta berakhlak mulia. } \\
\text { Akhlak mulia mencakup etika, } \\
\text { budi pekerti, atau moral sebagai } \\
\text { perwujudan dari pendidikan } \\
\text { agama. }\end{array}$ \\
\hline
\end{tabular}

\begin{tabular}{|c|c|c|}
\hline No & $\begin{array}{c}\text { Kelompok } \\
\text { Mata } \\
\text { Pelajaran }\end{array}$ & Cakupan \\
\hline 2. & $\begin{array}{l}\text { Kewargan } \\
\text { ega-raan } \\
\text { dan } \\
\text { Kepribadia } \\
\text { n }\end{array}$ & $\begin{array}{l}\text { Kelompok mata pelajaran } \\
\text { kewarganegaraan dan kepribadian } \\
\text { dimaksudkan untuk peningkatan } \\
\text { kesadaran dan wawasan peserta } \\
\text { didik akan status, hak, dan } \\
\text { kewajibannya dalam kehidupan } \\
\text { bermasyarakat, berbangsa, dan } \\
\text { bernegara, serta peningkatan } \\
\text { kualitas dirinya sebagai manusia. } \\
\text { Kesadaran dan wawasan termasuk } \\
\text { wawasan kebangsaan, jiwa dan } \\
\text { patriotisme bela } \\
\text { penghargaan terhadap hak-hak } \\
\text { asasi manusia, kemajemukan } \\
\text { bangsa, pelestarian lingkungan } \\
\text { hidup, kesetaraan gender, } \\
\text { demokrasi, tanggung jawab sosial, } \\
\text { ketaatan pada hukum, ketaatan } \\
\text { membayar pajak, dan sikap serta } \\
\text { perilaku anti korupsi, kolusi, dan } \\
\text { nepotisme. }\end{array}$ \\
\hline 3. & $\begin{array}{l}\text { Ilmu } \\
\text { Pengetahu } \\
\text { an dan } \\
\text { Teknologi }\end{array}$ & $\begin{array}{l}\text { Kelompok mata pelajaran ilmu } \\
\text { pengetahuan dan teknologi pada } \\
\text { SD/MI/SDLB dimaksudkan untuk } \\
\text { mengenal, menyikapi, dan } \\
\text { mengapresiasi ilmu pengetahuan } \\
\text { dan teknologi, serta menanamkan } \\
\text { kebiasaan berpikir dan berperilaku } \\
\text { ilmiah yang kritis, kreatif dan } \\
\text { mandiri. } \\
\text { Kelompok mata pelajaran ilmu } \\
\text { pengetahuan dan teknologi pada } \\
\text { SMP/MTs/SMPLB dimaksudkan } \\
\text { untuk memperoleh kompetensi } \\
\text { dasar ilmu pengetahuan dan } \\
\text { teknologi serta membudayakan } \\
\text { berpikir ilmiah secara kritis, } \\
\text { kreatif dan mandiri. } \\
\text { Kelompok mata pelajaran ilmu } \\
\text { pengetahuan dan teknologi pada } \\
\text { SMA/MA/SMALB dimaksudkan } \\
\text { untuk memperoleh kompetensi } \\
\text { lanjut ilmu pengetahuan dan } \\
\text { teknologi serta membudayakan } \\
\text { berpikir ilmiah secara kritis, } \\
\text { kreatif dan mandiri. }\end{array}$ \\
\hline 4. & Estetika & $\begin{array}{l}\text { Kelompok mata pelajaran estetika } \\
\text { dimaksudkan untuk meningkatkan } \\
\text { sensitivitas, kemampuan } \\
\text { mengekspresikan dan kemampuan } \\
\text { mengapresiasi keindahan dan } \\
\text { harmoni. } \\
\text { mengapresiasi } \\
\text { mengekspresikan keindahan serta } \\
\text { harmoni mencakup apresiasi dan } \\
\text { ekspresi, baik dalam kehidupan } \\
\text { individual sehingga mampu } \\
\text { menikmati dan mensyukuri hidup, } \\
\text { maupun dalam kehidupan } \\
\text { kemasyarakatan sehingga mampu }\end{array}$ \\
\hline
\end{tabular}




\begin{tabular}{|c|c|c|}
\hline No & $\begin{array}{c}\text { Kelompok } \\
\text { Mata } \\
\text { Pelajaran }\end{array}$ & Cakupan \\
\hline & & $\begin{array}{l}\text { menciptakan kebersamaan yang } \\
\text { harmonis. }\end{array}$ \\
\hline 5. & $\begin{array}{l}\text { Jasmani, } \\
\text { Olahraga } \\
\text { dan } \\
\text { Kesehatan }\end{array}$ & $\begin{array}{l}\text { Kelompok mata pelajaran jasmani, } \\
\text { olahraga dan kesehatan pada } \\
\text { SD/MI/SDLB dimaksudkan untuk } \\
\text { meningkatkan potensi fisik serta } \\
\text { menanamkan sportivitas dan } \\
\text { kesadaran hidup sehat. } \\
\text { Kelompok mata pelajaran jasmani, } \\
\text { olahraga dan kesehatan pada } \\
\text { SMP/MTs/SMPLB dimaksudkan } \\
\text { untuk meningkatkan potensi fisik } \\
\text { serta membudayakan sportivitas } \\
\text { dan kesadaran hidup sehat. } \\
\text { Kelompok mata pelajaran jasmani, } \\
\text { olahraga dan kesehatan pada } \\
\text { SMA/MA/SMALB/SMK/MAK } \\
\text { dimaksudkan untuk meningkatkan } \\
\text { potensi fisik serta membudayakan } \\
\text { sikap sportif, disiplin, kerja sama, } \\
\text { dan hidup sehat. } \\
\text { Budaya hidup sehat termasuk } \\
\text { kesadaran, sikap, dan perilaku } \\
\text { hidup sehat yang bersifat } \\
\text { individual ataupun yang bersifat } \\
\text { kolektif kemasyarakatan seperti } \\
\text { keterbebasan dari perilaku seksual } \\
\text { bebas, kecanduan narkoba, } \\
\text { HIV/AIDS, demam berdarah, } \\
\text { muntaber, dan penyakit lain yang } \\
\text { potensial untuk mewabah. }\end{array}$ \\
\hline
\end{tabular}

\section{a. Mata pelajaran}

Mata pelajaran beserta alokasi waktu untuk masing-masing di atas berpedoman pada struktur kurikulum yang tercantum dalam SI.

\section{b. Muatan Lokal}

Muatan lokal merupakan kegiatan kurikuler untuk mengembangkan kompetensi yang disesuaikan dengan ciri khas dan potensi daerah, termasuk keunggulan daerah, yang materinya tidak sesuai menjadi bagian dari mata pelajaran lain dan atau terlalu banyak sehingga harus menjadi mata pelajaran tersendiri. Substansi muatan lokal ditentukan oleh satuan pendidikan, tidak terbatas pada mata pelajaran keterampilan. Muatan lokal merupakan mata pelajaran, sehingga satuan pendidikan harus mengembangkan Standar Kompetensi dan Kompetensi Dasar untuk setiap jenis muatan lokal yang diselenggarakan. Satuan pendidikan dapat menyelenggarakan satu mata pelajaran muatan lokal setiap semester, Ini berarti bahwa dalam satua tahun satuan pendidikan dapat menyelenggarakan dua mata pelajaran muatan lokal.

\section{c. Strategi Pendidikan dan Pembelajaran}

Madrasah Aliyah Muhammadiyah Metro dalam mencapai visi, misi dan tujuan yang ingin dicapai, ada beberapa strategi pendidikan dan pembelajaran yang dilakukan, yaitu :

1. Proses pendidikan dan pembelajaran terintegrasi dengan nilai-nilai Islam dan diperkuat dengan Pendidikan di Pondok Darul Arqom. Pendidikan yang dimaksud adalah pendidikan dengan mengintegrasikan prinsip nilai-nilai islam untuk setiap mata pelajaran, baik pelajaran umum maupun pelajaran wajib dan di perdalam dengan pendidikan di Pondok Darul Arqom

2. Proses pendidikan dan pembelajaran dilaksanakan dalam bentuk full day school. Pembelajaran full day school (pembelajaran sehari penuh mulai pukul 07.00 s.d 14.30 kecuali hari jum'at dan sabtu) dilaksanakan selama 6 (enam) hari efektif (Senin Sabtu).

3. Proses pendidikan dan pembelajaran untuk tahap selanjutnya akan menerapkan konsep boarding school. Strategi ini dalam rangka memberikan 
penguatan kepada para peserta didik dalam melakukan pendalaman, pemahaman, sebagai upaya pembentukan karakter dan penanaman nilai-nilai akidah, dan pembinaan melalui amal ibadah sehari-hari, hadirnya Ponpes Darul Arqom adalah langkap yang tepat untuk menerapkan konsep Boarding School.

4. Menjadikan peserta didik sebagai subjek pendidikan dan pembelajaran. Dalam praksisnya bagaimana menjadikan peserta didik sebagai individu yang aktif belajar, menggali seluas mungkin ilmu pengetahuan, dan guru menjadi pendamping, pembimbing dan fasilitator pendidikan dan pembelajaran dalam menfasilitasi pengembangan potensi, bakat dan kemampuan peserta didik;

5. Proses pendidikan pendidikan dan pembelajaran dilaksanakan secara kontekstual CTL. (Contextual Teaching and Learning) Model pembelajaran yang mengaitkan antara materi yang diajarkannya dengan situasi dunia nyata siswa dan mendorong siswa membuat hubungan antara pengetahuan yang dimilikinya dengan penerapannya dalam kehidupan mereka sebagai anggota keluarga dan masyarakat

6. Menjadikan masjid sebagai pusat pembelajaran dan pengembangan keilmuanwarga sekolah. Masjid secara fisik dan mental dijadikan sebagai tempat bagi pengembangan berbagai aktifitas kajian, pembelajaran, dan pelatihan yang berbasis nilai-nilai Islam;

7. Proses pendidikan dan pembelajaran didukung dengan basis teknologi informasi. Kualitas sarana dan prasarana pendidikan dan pembelajaran berbasis teknologi informasi adalah untuk menjawab tantangan dan kebutuhan efektifitas dan efesiensi proses kegiatan belajar mengajar yang lebih berkemajuan;

8. Selama proses pendidikan dan pembelajaran, siswa didampingi oleh Guru yang professional sesuai bidadnya. Proses ini dilakukan dalam rangka pengembangan diri, mencapai tugas-tugas perkembangan secara optimal, membentuk kepribadian (personality) yang mandiri serta mendampingi/membantu siswa dalam memecahkan masalah pribadi, sosial, belajar dan karirnya.

9. Proses pendidikan dan pembelajaran model pendekatan empirik. Pembelajaran yang lebih menekankan aktivitas yang dilakukan oleh para peserta didik selama masa pembelajaran.

10. Proses Pendidikan dan Pembelajaran model pendekatan inquiry. Pembelajaran yang mengkombinasikan rasa ingin tahu siswa dan metode ilmiah. Penggunaan strategi ini untuk meningkatkan pengembangan keterampilan berpikir kritis melalui kegiatan belajar seperti pada bidang sains. Dorongan itu berkembang melalui proses merumuskan pertanyaan, merumuskan masalah, mengamati, dan menerapkan informasi baru dalam meningkatkan pemahaman mengenai sesuatu masalah. Rasa ingin tahu itu terus ditumbuhkan untuk meningkatkan semangat bereksplorasi sehingga siswa belajar secara aktif.

11. Proses Pendidikan dan Pembelajaran Model Pendekatan Kooperatif. 
Kegiatan belajar yang dilakukan oleh siswa dalam kelompok-kelompok tertentu untuk mencapai tujuan pembelajaran yang telah dirumuskan.

\section{d. Keunggulan Madrasah Aliyah Muhammadiyah Metro}

Adapun dalam Pembentukan keunggulan Madrasah Aliyah Muhammadiyah Metro akan diwujudkan dalam bentuk pengembangan Bakat, Minat dan Potensi (BMP) siswa. Pengembangan Bakat, Minat Dan Potensi (BMP) siswa dilatih dan didampingi secara intensif oleh guru dan pelatih professional yang memiliki kompetensi di bidangnya.

Adapun keunggulan yang ditawarkan oleh MA Muhammadiyah Metrodapat terlihat dalam tabel berikut ini:

\section{Tabel 4.}

KeunggulanMA Muhammadiyah MetroMetro

\begin{tabular}{|c|c|}
\hline$\overline{\text { Keunggulan }}$ & Aspek Keunggulan \\
\hline Unggul Agama & $\begin{array}{ll}\text { 1. } & \text { Pengamalan Islam secara } \\
\text { Benar } \\
\text { 2. Tartil dalam Membaca Al- } \\
\text { Qur`an, } \\
\text { 3. Hafizd Quran 5 Jus, } \\
\text { 4. Hafal 100 hadits Pilihan } \\
\text { 5. Mampu berkhutbah/ceramah } \\
\text { 6. Menjadi ulama'/ kyai, } \\
\text { ustdaz/ustadzah, da'i/daiyah, } \\
\text { imam tetap masjid }\end{array}$ \\
\hline $\begin{array}{l}\text { Unggul } \\
\text { berbahasa } \\
\text { asing }\end{array}$ & $\begin{array}{l}\text { 1. Pidato/Percakapan bahasa } \\
\text { Arab dan Inggris. }\end{array}$ \\
\hline $\begin{array}{l}\text { Unggul Olah } \\
\text { Raga }\end{array}$ & $\begin{array}{ll}\text { 1. } & \text { Beladiri Tapak Suci, } \\
\text { 2. } & \text { Futsal/Football, } \\
\text { 3. } & \text { Atletik, } \\
\text { 4. } & \text { Folyball, } \\
\text { 5. } & \text { Badminton, } \\
\text { 6. } & \text { Tennis, } \\
\text { 7. } & \text { Catur, dll. }\end{array}$ \\
\hline $\begin{array}{l}\text { Unggul } \\
\text { Science }\end{array}$ & $\begin{array}{ll}\text { 1. } & \text { Matematika, } \\
\text { 2. IPS dan } \\
\text { 3. }\end{array}$ \\
\hline Unggul Seni & $\begin{array}{ll}\text { 1. } & \text { Kaligrafi, } \\
\text { 2. } & \text { Qori'/ Qoriah } \\
\text { 3. } & \text { Life skill Design Grafis }\end{array}$ \\
\hline $\begin{array}{l}\text { Kecakapan } \\
\text { Hidup }\end{array}$ & $\begin{array}{ll}\text { 1. } & \text { Enterpreunership, } \\
\text { 2. } & \text { Kepanduan, } \\
\text { 3. } & \text { Jurnalistik, dan } \\
\text { 4. } & \text { Leadership Tranning }\end{array}$ \\
\hline
\end{tabular}

Pembinaan keunggulan siswa dilakukan dalam bentuk kegiatan ekstrakurikuler yang dibina secara intensif, sistematik, berkelanjutan dan professional. Selanjutnya prestasi siswa akan diikutsertakan pada kompetisi-kompetisi mulai dari tingkat lokal, regional, nasional hingga internasional.

Tujuan Pengembangan Diri adalah untuk mengembangkan dan mengekspresikan diri sesuai dengan kebutuhan, bakat, dan minat setiap peserta didik sesuai kondisi sekolah. Kegiatan pengembangan diri difasilitasi dan atau dibimbing oleh Konselor, Guru dan Tenaga Kependidikan, yang dilakukan dalam bentuk kegiatan ekstrakurikuler.

a. Kegiatan Pengembangan diri dilakukan melalui pelayanan konseling yang berkenaan dengan masalah diri pribadi dan kehidupan sosial, belajar, dan pengembangan karir peserta didik

b. Kegiatan Pengembangan diri juga dilakukan melalui kegiatan ekstra kurikuler yang meliputi :

1) Kelompok Kewiraan

Kegiatan kelompok kewiraan terdiri dari :

a) Hizbul Wathon (HW)

b) Palang Merah Remaja (PMR)

c) Unit Kesehatan Sekolah (UKS)

Strategi pelaksanaan program untuk kegiatan Hizbul Wathon diikuti oleh siswa kelas X-XII pada semester I dan II (kecuali kelas XII pada semester II), dan untuk kegiatan PMR, UKS dikuti oleh siswa pilihan kelas $\mathrm{X}$ dan XI.

Tujuan dilaksanakannya kegiatan ini adalah : 
a) Menumbuhkan sikap percaya diri, bertanggung jawab terhadap tugas, disiplin,terampil dan mandiri

b) Menumbuhkan sikap cinta tanah air dan nasionalisme

c) Menumbuhkan sikap menghormati dan menghargai oerang lain dan bersikap terbuka dalam menerima masukan

2) Kelompok Olahraga

Kelompok Olahraga terdiri dari :

a) Sepak bola/ Futsal

b) Atletik

c) Folyball

d) Bulu tangkis

e) Beladiri Tapak Suci Putra Muhammadiyah

Strategi pelaksanaan kegiatan ini dilaksakan pada semester I dan II, menjadi media untuk mendorong pertumbuhan fisik, perkembangan psikis, keterampilan motorik.

Tujuan dilaksanakannya kegiatan dalam bidang olahraga ini ialah:

a) Mengembangkan keterampilan pengelolaan diri dalam upaya mengembangkan dan memlihara kebugaran jasmani serta pola hidup sehat

b) Meningkatkan pertumbuhan fisik

c) Meningkatkan kemampuan dan keterampilan gerak dasar

d) Mengembangkan keterampilan untuk menjaga keselamatan sendiri, orang lain dan lingkungan

e) Mempersiapkan atlit usia dini

3) Kelompok Seni

Kegiatan kelompok seni terdiri dari:
a) Seni Kaligrafi
b) Seni Vokal/paduan suara atau nasyid
c) Seni Qiroatul Quran

Strategi pelaksanaan kegiatan ini adalah ditangani secara profesional dengan dukungan sumber daya manusia yang cakap, menggunakan fasilitas yang memadai, pelatihan-pelatihan baik secara formal maupun non formal dilaksanakan dengan tahapan persiapan dan tahapan pelaksanaan.

Tujuan kegiatan ini adalah untuk :

a) Menumbuhkan kehalusan budi pekerti, kemandirian serta tanggung jawab

b) Memahami konsep dan pentingnya kegiatan seni

c) Menampilkan sikap apresiasi terhadap seni budaya

d) Menampilkan kreativitas melalui seni budaya

e) Meningkatkan dan memantapkan pengetahuan siswa tentang seni qiroatul Quran

4) Kelompok Ilmiah

Kegiatan kelompok ilmiah terdiri dari:

a) Kelompok Ilmiah Remaja (KIR). Strategi pelaksanaan kegiatan ini adalah dengan menyiapkan tenaga pembimbing profesional dengan dukungan biaya yang memadai yang disiapkan melalui RAB sekolah, kegiatan dilaksanakan dengan interaktif (fun, fresh, focus) Tujuan kegiatan ini adalah untuk:

a) Menumbuhkembangkan

kemampuan siswa untuk mengungkapkan imajinasi yang dirasakan dari melihat atau mengalami kejadian serta menilai suatu kejadian

b) Mengembangkan minat bakat siswa dalam bidang pengolahan elektronik sampai kepada ahli elektronik 
c) Menumbuhkan kepedulian siswa terhadap lingkungan sehat sehingga menjadikan sampah sebagai sesuatu yang bermanfaat

\section{5) Kelompok Bahasa}

Kegiatan kelompok bahasa terdiri dari bahasa Inggris dan Arab. Adapun bentuk kegiatan kelompok bahasa yaitu :

a) Pidato

b) Percakapan

Strategi pelaksanaan menyiapkan fasilitator profesional dan siswa pilihan, mengadakan latihan-latihan secara formal dan non formal, kegiatan ini dilaksanakan pada semester I dan II.

Tujuan kegiatan ini adalah untuk :

a) Menggairahkan semangat peserta didik untuk dapat melaksanakan bulan dan minggu bahasa Inggris dan Arab

b) Menumbuhkan kemampuan berbahasa Inggris dan bahasa Arab

\section{e. Program Pembiasaan}

Ada dua program pembiasaan yaitu pembiasaan rutin dan terprogram. Dengan penjelasan sebagai berikut :

\section{Pembiasaan Rutin}

Kegiatan pembiasaan rutin terdiri dari :

1) Sholat sunnah Dhuha;

2) Sholat Dzuhur berjama'ah;

3) Kuliah tujuh menit (Kultum);

4) Tadarus Al-Quran;

5) Pembinaan Tilawah Al-Quran;

6) Mengucapkan salam bila bertemu dan berpisah;

7) Mengucapkan BismillahAlhamdulillah dalam mengawali dan mengakhiri pekerjaan baik;

8) Mengucapkan terima kasih diiringi ungkapan Alhamdulillah;
9) Meminta dan memberi maaf terhadap sesama;

10) Pengamalan puasa sunnah.

Strategi pelaksanaan menjadikan guru dan orangtua sebagai tokoh pertama yang dapat ditiru dan menjadikan diri setiap siswa sebagai ibda' binafsih. Sistem pembinaan dilakukan dengan bentuk pembiasaan, pelatihan baik formal maupun non formal, dengan menekankan pada kegiatan praktis.

Tujuan kegiatan ini adalah untuk :

1) Pembentukan akhlak dan penanaman/pengamalan ajaran Islam

2) Menanamkan nilai akhlak mulia.

Dengan demikian akan tercapainya exploring moral engagement should be regarded to provide the framework of interactional basis with human communities such as trust, care, friendship, and commitment. This attempt can also underlie virtual interaction by providing an innovative way to help the human society in a good life ${ }^{13}$, maksudnya adanya keterlibatan orangtua dan guru harus dianggap memberikan kerangka dasar interaksi antar manusia dengan membangun komunitas bersama seperti kepercayaan, saling menjaga, persahabatan, dan komitmen untuk mencapai akhlak yang mulia. Usaha ini juga bisa mendasari virtual interaksi dengan memberikan cara inovatif untuk membantu dalam kehidupan yang baik di lembaga tersebut.

${ }^{13}$ Miftachul Huda, M. Ihsan Dacholfany, and friends, From Live Interaction To Virtual Interaction: Addressing Moral Engagement In The Digital Era, Journal of Theoretical and Applied Information Technology, 5th October, Vol. 95. No 19. 2017. P.4970, 


\section{Pembiasaan Terprogram}

Kegiatan pembiasaan terprogram terdiri dari :

1) Pengkaderan Taruna Melati

Kegiatan pengkaderan Taruna Melati wajib diikuti oleh kelas $\mathrm{X}$ yang dilaksanakan pada bulan Juli minggu ke tiga selama 4 (empat) hari 3 malam dan menginap di sekolah.kegiatan ini diprogram dan kelolah PD IPM bekerjasama dengan pihak sekolah.

Sedangkan kegiatan pengkaderan Baitul Arqom wajib diikuti oleh kelas XI dan XII yang dilaksanakan setiap akhir semester minimal sekali setiap tahunnya. Kegiatan ini di program dan kelola oleh sekolah.

2) Da'i Hijrah

Kegiatan ini wajib diikuti oleh seluruh siswa yang telah terpilih memenuhi syarat dan ketentuan dalam berceramah. Kegiatan ini dilaksanakan minimal selama 10 (sepuluh) hari di bulan Ramadhan dan terjunkan ke daerah-daerah yang telah ditentukan

Strategi pelaksanaan mengisi kegiatan Ramadhan menjelang libur akhir Ramadhan, kemudian hari-hari awal belajar bulan Juli dan setelah ujian semester. Sistem pembinaan dilakukan dengan bentuk pembiasaan, pelatihan baik formal maupun non formal, dengan menekankan pada kegiatan praktis.

Tujuan kegiatan ini adalah untuk:

1) Penanaman pengetahuan, pemahaman dan pengamalan nilai-nilai ajaran Islam

2) Menanamkan nilai akhlaq mulia kepada peserta didik

3) Melatih mental dan kemampuan vocal siswa dalam berbicara di depan umum.

\section{Program Keteladanan}

Program keteladanan terdiri dari :

1) Pembinaan ketertiban pakaian seragam

2) Pembinaan kedisiplinan

3) Penanaman nilai akhlaq Islami

4) Penanaman budaya baca

5) Penanaman budaya keteladanan:

a) Budaya lingkungan hijau

b) Budaya bersih diri

c) Budaya bersih lingkungan kelas/sekolah

Strategi pelaksanaaan seluruh warga sekolah diwajibkan melaksanakan dibentuk melalui pikiran dan perasaan dan keyakinan bukan untuk mendapatkan pujian/hadiah atau menghindari hukuman.

\section{Kegiatan Nasionalisme dan Patriotisme}

Kegiatan untuk membangun rasa nasionalisme dan patriotisme warga sekolah terdiri dari :

1) Peringatan Hari Kemerdekaan RI

2) Peringatan Hari Pahlawan

3) Peringatan Hari Pendidikan Nasional

4) Peringatan Hari Amal Bakti Kemenag

5) Peringatan Hari Sumpah Pemuda

6) Peringatan Hari Kesaktian Pancasila

Strategi kegiatan nasionalisme dan patriotisme dilaksanakan dengan mengadakan upacara peringatan, pawai ta'aruf, dan lomba kebersihan dan keindahan antar kelas.

Tujuan dilaksanakan adalah untuk :

1) Menumbuhklan rasa cinta tanah air

2) Menumbuhkan jiwa kepahlawan dan kesederhanaan

3) Menumbuhkan kepribadian jujur, bertanggung jawab dan mandiri

\section{Pekan Kreativitas Siswa}

Pekan kreatif siswa dilaksanakan dalam rangkaian kegiatan Lomba Kreativitas dan Karya Cipta. 
Strategi pelaksanaan dengan memanfaatkan hari-hari tidak efektif setelah ujian semester, setiap kelas menghasilkan produk kreativitas melaksanakan lomba pada waktu-waktu yang ditentukan minimal sekali dalam satu tahun. Program ini disebut juga program classmeting

Tujuan dilaksanakan adalah untuk :

a) Mengembangkan kemampuan siswa untuk menghasilkan karya

b) Menumbuhkan rasa percaya diri siswa yang besar

c) Menghasilkan karya murni anak-anak

\section{Pembinaan dan Bimbingan Siswa Olimpiade}

Pembinaan dan bimbingan olimpiade untuk siswa terdiri dari :

1) KSM (Kompetisi Sains Madrasah)

2) AKSIOMA (Ajang Kompetisi Seni dan Olahraga Madrasah)

3) Ajang Kompetisi Lintas Fortasi

4) Kompetisi Futsal

5) OSN, dan lain sebagainya

Pembinaan dan bimbingan siswa peserta olimpiade dilaksanakan secara berkala, terjadwal dan sampai kepada pemusatan latihan.

Tujuan dilaksanakan adalah :

1) Membekali siswa agar lebih siap menghadapi lomba-lomba olimpiade

2) Penguatan wawasan para peserta olimpiade

3) Menyiapkan calon peserta olimpiade agar lebih berkualitas

\section{Outdoor Learning \& Training}

1. Kunjungan Belajar

2. Outbound

Pelaksanaan kegiatan ini dilakukan secara terencana dan terjadwal dengan mempertimbangkan kebutuhan masingmasing kegiatan. Kegiatan melibatkan orang tua dan dilaksanakan pada hari sabtu.

Tujuan dilaksanakan adalah : (1). Melatih kemandirian siwa, (2). Melatih tanggung jawab siswa, (3). Memberi kebebasan siswa berekspresi seluasluasnya, (4). Memperarat tali silaturahmi seluruh warga sekolah

\section{KESIMPULAN}

Berdasarkan hasil penelitian dan pembahasan yang dilakukan penulis dengan judul "Manajemen Strategi Pelaksanaan Kurikulum Dalam Mewujudkan Madrasah Aliyah Muhammadiyah Metro Menjadi Sekolah Unggul" maka dapatlah disimpulkan:

1. Madrasah Aliyah Muhammadiyah Metro untuk mencapai visi, misi dan tujuan yang telah ditetapkan telah melaksanakan proses perencanaan, pengorganisasian, penggerakan dan pengawasan. Dari data yang kami kumpulkan dengan menggunakan pisau analisis masalah, materi/isi dan topik bahasan dapat disimpulkan bahwa secara obyektif Madrasah Aliyah Muhammadiyah Metro memiliki bekal yang cukup untuk menjadi penyelenggara pendidikan yang unggul bahkan terunggul di Kota Metro.

2. Beberapa strategi pelaksanaan kurikulum dalam mewujudkan Madrasah Aliyah Muhammadiyah Metro menjadi sekolah unggul sudah sesuai dengan konsepsi dalam dunia pendidikan, seperti:Proses pendidikan dan pembelajaran terintegrasi dengan nilai-nilai Islam dan diperkuat dengan Pendidikan di Pondok Darul Arqom, proses pendidikan dan pembelajaran dilaksanakan dalam bentuk full day 
school (pembelajaran sehari penuh mulai pukul 07.00 s.d 14.30 kecuali hari Jum'at dan Sabtu) dilaksanakan selama 6 (enam) hari efektif (Senin Sabtu), berikutnya menjadikan peserta didik sebagai subjek pendidikan dan pembelajaran, yang tidak kalah pentingnya proses pendidikan dan pembelajaran dilaksanakan secara Contextual Teaching and Learning dan berikutnya selama proses pendidikan dan pembelajaran, siswa didampingi oleh Guru yang professional sesuai bidangnya.

3. Dimensi keunggulan Madrasah Aliyah Muhammadiyah Metro sebagai ciri sekolah unggul sudah terpenuhi seperti: adanya input, sarana prasarana penunjang, lingkungan belajar, guru dan tenaga kependidikan, kurikulum, proses belajar, dan memberikan manfaat. Hanya pengamatan yang penulis lakukan siswa yang masuk belum sesuai harapan sehingga tidak ada seleksi ketat dengan menggunakan kriteria tertentu dan prosedur yang dapat dipertanggungjawabkan, selanjutnya lingkungan belajar belum kondusif untuk berkembangnya potensi keunggulan yang nyata baik lingkungan fisik maupun sosial psikhologis karena pondok pesantren Darul Arqom sebagai boarding school dan daya tarik tersendiri bagi peserta dan orang tua didik belum menyatu dengan sekolah itu sendiri dan lingkungan sekolah berada dalam komplek pendidikan (SDM, MTSM, SMAM) yang kurang memadai/sempit.

\section{DAFTAR PUSTAKA}

A. Tafsir, Strategi Meningkatkan Mutu Pendidikan Agama Islam, Bandung: Maestro, 2008.

Fred David, Manajemen Strategis, Jakarta Salemba, Ce.-4. 2006.

Husni Rahim, Arah Baru Pendidikan Islam di Indonesia, Jakarta: Logos, 2001.

M.Ihsan Dacholfany, Peran Kepemimpinan Perguruan Tinggi Islam dalam Pembagunan Peradaban islami, Jurnal Nizam : Studi Keislaman, No. 02 Juli Desember 2013.

M.Ihsan Dacholfany, Reformasi

Pendidikan Islam Dalam

Menghadapi Era Globalisasi:

Sebuah Tantangan Dan Harapan, Jurnal Akademika, Vol. 20, No. 01 Januari - Juni 2015.

Miftachul Huda, M. Ihsan Dacholfany, and friends, From Live Interaction To Virtual Interaction: Addressing Moral Engagement In The Digital Era, Journal of Theoretical and Applied Information Technology, 5th October, Vol.95. No 19. 2017.

Nurcholis Madjid, Islam Doktrin Dan Peradaban: Sebuah Telaah Kritis Tentang Masalah Keimanan, Kemanusiaan Dan Kemoderenan:, Jakarta: Yayasan wakaf paramadina, 1992.

Sugiyono, Metode Penelitian Pendidikan

(Pendekatan Kuantitatif, Kualitatif, dan $R \& D)$, Bandung: Alfabeta, 2010.

Tunggal Amin Widjaja, Audit Manajemen, Jakarta, 2011. 
Wheelen dan Hunger, Manajemen

Stratejik, Terj. Julianto Agung,

Yaogyakarta, Penerbit Andi, 2008. 